The first two experiments realized with a total of 164 pigs showed an optimum utilization of "Gluten-feed " correctly supplemented with lysine $(20$ p. Ioo). Thus, a partial substitution of complementary soya-bean proteins (about $25 \mathrm{p}$. Ioo) is possible

Likewise, experiment 3 made on 96 pigs, clearly showed that a gluten mixture (40 p. Ioo Gluten-feed +60 p. Ioo maize gluten) at 44 p. Ioo protein correctly re-balanced with lysine and used at a level of $25 \mathrm{p}$. I00, can provide $75 \mathrm{p}$. 100 of the complementary supply of protein.

The last digestibility experiment on $\mathrm{I} 6$ pigs allowed determination of the energy value of "Gluten-Feed \#, 2 goo kcal digestible energy/kg dry matter, corresponding to an apparent digestibility coefficient $(\mathrm{ADC})$ of the energy of $64 \mathrm{p}$. roo.

\title{
VALEUR NUTRITIVE DE L'URÉE \\ COMME SOURCE D'AZOTE INDIFFÉRENCIÉ \\ EN PRÉSENCE OU NON DE LACTOSE CHEZ LE PORC EN CROISSANCE-FINITION
}

\author{
A. RÉRAT et D. BOURDON \\ Laboratoire de Physiologie de la Nutrition, \\ Station de Recherches sur l'Élevage des Porcs, \\ Centre national de Recherches zootechniques, I. N.R. A., \\ 78350 Jouy en Josas
}

\section{RÉSUMÉ}

Deux expériences ont été réalisées en vue de préciser si la présence de glucides à digestion lente (lactose) introduits en quantité élevée, est susceptible de favoriser l'utilisation nutritive de l'urée chez le Porc en croissance-finition.

La première expérience a été réalisée sur 9 lots de 12 porcs ( 6 mâles castrés, 6 femelles). Les 8 régimes expérimentaux diffèrent du régime témoin semi-synthétique ( $\mathrm{I} 2 \mathrm{p}$. 1oo de farine de poisson), par substitution d'une fraction de protéines (3 p. Ioo) à l'aide d'urée ( $\mathrm{r}$ p. roo), et/ou d'un mélange rééquilibrant en acides aminés indispensables, et/ou par substitution d'une fraction (3o p. Ioo) des glucides de base (amidon ou maïs) par du lactose.

En alimentation semi ad libitum, l'addition d'urée se traduit par aucun effet bénéfique, ni sur la croissance, ni sur l'indice de consommation, pas plus que sur la composition corporelle, que ce soit en présence ou en l'absence d'un mélange rééquilibrant d'acides aminés indispensables et/ou de lactose. Par contre, l'addition de ces derniers, séparément ou ensemble, en présence ou en l'absence d'urée se révèle bénéfique.

La deuxième expérience réalisée en cage à métabolisme sur 16 castrats présente des modalités différentes : alimentation égalisée par paires, comparaison d'un régime témoin à I 2 p. Ioo de protéines de poisson avec 3 régimes expérimentaux dans lesquels 2 p. roo des protéines sont 
remplacées par de l'urée (o,7 p. Ioo) et un mélange rééquilibrant d'acides aminés indispensables et dans lesquels une fraction ( $30 \mathrm{p}$. Ioo) de l'amidon de maïs est remplacée (ou non) par du lactose.

Dans ces conditions, la substitution du mélange d'urée et d'acides aminés indispensables aux protéines de poisson ne provoque aucun effet significatif sur la digestibilité ou la rétention de l'azote; on note cependant une tendance à l'augmentation du coefficient d'utilisation digestive en présence de ce composé.

Le lactose provoque une diminution de 2 points en moyenne de l'utilisation digestive de l'énergie. Il apparaît donc qu'en alimentation restreinte, la valeur nutritive d'un régime bien équilibré ne semble pas modifiée par la substitution d'une faible proportion de ses protéines de base par un mélange d'urée $(0,7 \mathrm{p}$. Ioo) et d'acides aminés indispensables.

En conclusion, il apparaît qu'en alimentation libérale et à taux de I p. 100 (3 p. Ioo $\mathrm{N} \times 6,25$ ), l'urée ne peut constituer une sourı d'azote indifférencié convenable pour des animaux à haute vitesse de croissance, même si la prolifération de la flore intestinale est favorisée à l'aide d'une incorporation de lactose dans le régime.

Par contre, en alimentation restreinte et pour une vitesse de croissance plus faible, il n'est pas exclu qu'une partie de l'urée fournie à taux plus réduit $(0,7 \mathrm{p}$. I0o, soit 2 p. Ioo $\mathrm{N} \times 6,25)$ puisse servir d'appoint d'azote indifférencié pour la synthèse protéique, cette utilisation n'étant pas modifiée par la présence de lactose dans le régime.

Dans les conditions de la pratique, on peut ainsi conclure que l'incorporation d'urée au régime ne peut être considérée comme un moyen d'économiser les protéines en raison des effets plutôt défavorables que ce corps provoque en alimentation libérale chez les monogastriques.

\section{SUMMARY}

\section{NUTRITIVE VALUE OF UREA AS A SOURCE \\ OF NON ESSENTIAL NITROGEN WITH OR WITHOUT \\ LACTOSE IN GROWING-FINISHING PIGS}

Two experiments were carried out in order to determine if the presence of slowly digested carbohydrates (lactose) incorporated in large quantities into the diet was able to favour the nutritive utilization of urea in the growing-finishing pig.

The first experiment was made on 9 groups of 12 pigs ( 6 castrated males, 6 females). The 8 experimental diets differed from the semi-synthetic control diets ( $12 \mathrm{p}$. Ioo fish-meal) by the substitution of part of the proteins (3 p. Ioo) by urea (I p. IOo) and/or by a rebalancing mixture of essential amino acids, and/or by substitution of part (30 p. 100) of the basal carbohydrates (maize starch) by lactose.

In semi ad libitum feeding, the addition of urea did not have any favourable effect, either on growth, food conversion ratio or body composition, in the presence or not of a rebalancing mixture of essential amino acids and/or of lactose. On the other hand, the addition of the latter, separately or together, in the presence or not of urea, appeared to be beneficial.

The second experiment, in metabolism crates, on 16 castrated animals was carried out according to a different schedule : paired feeding, comparison between a control diet with 12 p. Ioo fish protein and 3 experimental diets in which 2 p. Ioo of the proteins were replaced by urea (0.7 p. IOo) and a rebalancing mixture of essential amino acids and/or a fraction ( 30 p. 100) of maize starch replaced by lactose.

Under these conditions, the substitution of fish proteins by the mixture of urea and essential amino acids did not have any significant effect on the digestibility or retention of nitrogen; however, a tendency towards increase of the apparent digestibility coefficient was noted in the presence of this component. 
Lactose brought about a mean decrease of 2 points, in the digestibility of the energy. Consequently, it appears that in restricted feeding the nutritive value of a well balanced diet, does not seem to be modified by the substitution of a small proportion of these basal proteins by a mixture of urea (0.7 p. Ioo) and essential amino acids.

It can be concluded that in liberal feeding urea, at a level of I p. $100(3 \mathrm{p}$. I $100 \mathrm{~N} \times 6.25)$, cannot be considered as an adequate source of non essential nitrogen for fastly growing animals, even if the proliferation of the intestinal flora is favoured by the incorporation of lactose into the diet.

On the other hand, in restricted feeding and in the case of a lower growth rate it is not excluded that part of the urea supplied at a lower level $(0.7$ p. Ioo i.e. 2 p. roo $\mathrm{N} \times 6.25)$ might be used to make up the non essential nitrogen for the synthesis of protein, as this utilization is not changed by the presence of lactose in the diet.

It may be concluded that in practice, the incorporation of urea into the diet cannot be considered as a means to spare proteins because of the unfavourable effects caused in liberally fed monogastric animals.

\title{
COMPARAISON DE TROIS CÉRÉLES : BLÉ, MÄ̈S, ORGE ET D'ASSOCIATIONS MÄIS-ORGE Maïs-BLE DANS DES Ra'tions POUR PORCS CHARCUTIERS
}

\author{
J. CASTAING et J. MOAL \\ Association générale des Producteurs de Maïs, \\ 1, Place Lestapis, \\ 64000 Pau
}

\section{RÉSUMÉ}

Nous avons voulu comparer la valeur d'utilisation du maïs, du blé et de l'orge et l'association à deux niveaux $(2 / 3-1 / 3-1 / 3-2 / 3)$ du maïs avec le blé ou l'orge dans des rations pour porcs charcutiers, de 25 à $103 \mathrm{~kg}$ de poids vif.

Les régimes sont établis de façon à respecter un rapport constant entre l'énergie digestible et les protéines $(20 \mathrm{kcal} / \mathrm{g}$ de protéines).

L'alimentation humide a été distribuée en deux repas journaliers. Les animaux ont été rationnés après une période d'alimentation semi ad libitum. Les plateaux de rationnement ont été calculés de telle sorte que les animaux reçoivent en finition 8 roo kcal d'énergie digestible, $415 \mathrm{~g}$ de matières azotées brutes et $23 \mathrm{~g}$ de lysine.

Sur l'ensemble croissance-finition l'efficacité énergétique et azotée est comparable quelle que soit la céréale ou le mélange de céréales utilisés. Les indices de consommation, exprimés en quantité d'aliment nécessaire par $\mathrm{kg}$ de gain de poids des animaux, sont en, liaison très étroite avec la concentration énergétique des régimes. Ils augmentent de 3, Io à 3,50 quand la concentration décroît de 3400 à $3500 \mathrm{kcal}$ d'énergie digestible (respectivement régimes à base de maïs et d'orge). 